\title{
Application of a multiplex PCR for the detection of protozoan pathogens of the eastern oyster Crassostrea virginica in field samples
}

\author{
Spencer Russell ${ }^{1}$, Salvatore Frasca Jr. ${ }^{1}$, Inke Sunila ${ }^{2}$, Richard A. French ${ }^{1, *}$ \\ ${ }^{1}$ Department of Pathobiology and Veterinary Science, U-3089, University of Connecticut, 61 North Eagleville Road, \\ Storrs, Connecticut 06269-3089, USA \\ ${ }^{2}$ Bureau of Aquaculture, Department of Agriculture, State of Connecticut, Milford, Connecticut 06460-0097, USA
}

\begin{abstract}
Populations of eastern oysters Crassostrea virginica along the east coast of North America have repeatedly experienced epizootic mass mortality due to infections by protozoan parasites, and molecular diagnostic methodologies are fast becoming more widely available for the diagnosis of protozoan diseases of oysters. In this study we applied a modified version of an existing multiplex polymerase chain reaction (PCR) for detection of the eastern oyster parasites Haplosporidium nelsoni, H. costale and Perkinsus marinus from field-collected samples. We incorporated primers for DNA quality control based on the large subunit ribosomal RNA (LSU rRNA) gene of $C$. virginica. The multiplex PCR (MPCR) simultaneously amplified genomic DNA of C. virginica, and cloned DNA of $H$. nelsoni, $P$. marinus and $H$. costale. In field trial applications, we compared the performance of the MPCR to that of the conventional diagnostic techniques of histopathological tissue examination and the Ray/Mackin fluid thioglycollate medium (RMFT) assay. A total of 530 oysters were sampled from 18 sites at 12 locations along the east coast of the United States from the Gulf of Mexico to southern New England. The modified MPCR detected $21 \%$ oysters with $H$. nelsoni, $2 \%$ oysters with $H$. costale, and $40 \%$ oysters with $P$. marinus infections. In comparison, histopathological examination detected $H$. nelsoni and $H$. costale infections in 6 and $0.8 \%$ oysters, respectively, and the RMFT assay detected P. marinus infection in $31 \%$ oysters. The MPCR is a more sensitive diagnostic assay for detection of $H$. nelsoni, H. costale, and P. marinus, and incorporation of an oyster quality control product limits false negative results.
\end{abstract}

KEY WORDS: Diagnostics - Eastern oyster - Haplosporidium costale $\cdot$ Haplosporidium nelsoni · Multiplex PCR $\cdot$ Perkinsus marinus $\cdot$ Quality control

\section{INTRODUCTION}

Protozoa, such as Haplosporidium nelsoni Haskin, Stauber and Mackin, 1966 (multinucleated sphere unknown, MSX), Haplosporidium costale Wood and Andrews, 1962 (seaside organism, SSO) and Perkinsus marinus Levine 1978 (Dermo disease), are the most common causes of disease in the eastern oyster and, since the 1950s, have accounted for serious, wide- spread, periodic oyster mortalities from the Gulf of Mexico to the shores of Maine (Mackin et. al. 1950, Andrews \& Hewett 1957, Haskin et al. 1966, Kleinschuster \& Parent 1995, Barber et al. 1997, Sunila et al. 1999).

Traditionally, Haplosporidium nelsoni and H. costale have been detected by identification of spore and plasmodial stages in histological sections of oyster tissue (Wood \& Andrews 1962, Andrews \& Castagna 1978). 
These methods are time-consuming and expensive, and histomorphological similarities between plasmodia of $H$. nelsoni and $H$. costale make diagnosis of mixed infections in the absence of species-defining spores difficult (Andrews \& Castagna 1978, Stokes \& Burreson 1995, 2001). In the case of Perkinsus marinus, the Ray/Mackin fluid thioglycollate (RMFT) assay is useful (Ray 1952, 1966). However, the assay fails to differentiate between the many different types of Perkinsus species found to infect mollusks worldwide (Robledo et al. 2000). It has been shown that 2 Perkinsus species may simultaneously affect the same individual host (Kotob et al. 1999, Coss et al. 2001). In addition, the RMFT assay has reportedly failed to detect infections below 1000 P. marinus parasites per gram wet tissue (Bushek et al. 1994).

Polymerase chain reaction (PCR) and DNA probe methodologies have been developed and used successfully for rapid detection of Haplosporidium nelsoni (Stokes et al. 1995, Stokes \& Burreson 2001), H. costale (Ko et al. 1995, Stokes \& Burreson 1995, 2001), and Perkinsus marinus (Marsh et al. 1995, Robledo et al. 1998). PCR is ideal for specifically recognizing target DNA sequences regardless of the life history stage of the parasite or host (Stokes et al. 1995). Simultaneous detection of multiple pathogens in a single $\mathrm{PCR}$ reaction utilizing multiplex PCR (MPCR) technology has proven to be a successful approach for rapid, sensitive and specific identification of protozoan agents in the eastern oyster (Penna et al. 2001). In addition, with an increased reliance on PCR-based diagnostic tests for pathogenic microorganisms, internal standards are useful to obtain reliable diagnosis and to avoid false negative results (Brightwell et al. 1998). MPCR is ideally suited for incorporation of an internal standard (Sachadyn \& Kur 1998); successful amplification of the internal standard confirms that the quality of DNA isolated from a sample will support amplification and that no inhibitors or technical failures were encountered.

The aim of this study was to modify an existing MPCR to include an internal standard for DNA quality control and to apply this modified MPCR in a large-scale field trial to assess its utility versus the conventional diagnostic techniques of histological examination and the RMFT assay.

\section{MATERIALS AND METHODS}

To introduce a host-specific amplicon into the MPCR protocol, primers to regions of the large subunit (LSU) ribosomal RNA (rRNA) sequence of Crassostrea virginica (GenBank Accession \#AF137050) were designed using DNAMAN analysis software (Lynnon Corp.). In order to obtain primers of similar lengths (19 to 21 nucleotides) and melting temperatures $( \pm 1$ to $2{ }^{\circ} \mathrm{C}$ ) to accommodate the incorporation of an internal standard, primer sets previously designed by Stokes et al. (1995), Ko et al. (1995), Marsh et al. (1995), and Penna et al. (2001) for the small subunit (SSU) rRNA gene sequences for Haplosporidium nelsoni, $H$. costale, and an intergenic non-transcribed sequence (NTS) between the 5S and SSU rRNA gene of Perkinsus marinus (GenBank Accession \#U19538, U20858 and S78416, respectively) were modified or redesigned (Table 1). Primers to the SSU rRNA gene of $H$. costale were not those used by Penna et al. (2001) or Ko et al. (1995), but instead were designed from a different section of the SSU rRNA gene sequence provided by Ko et al. (1995). Putative primer sequences were aligned and checked against the SSU rRNA gene sequences of Haplosporidium louisiana (\#U47851), Urosporidium crescens (\#U47852), Minchinia teredinis (\#U20320), the ciliates Oxytricha nova (\#X03948), Tetrahymena pyriformes (\#M98021) and Paramecium tetraurelia (\#X03772), the dinoflagellates Crypthecodinium cohnii (\#M64245), Symbiodinium corculorum (\#L13717), Prorocentrum micans (\#M14649), and Amphidinium belauense (\#L13719). Forward and reverse primers for C. virginica, $H$. nelsoni, $P$. marinus, and $H$. costale were synthesized by Life Technologies. DNA was extracted using the Qiagen DNeasy tissue extraction and purification system, with several modifications to the manufacturer's animal tissue protocol. Briefly, tissue samples of gill, mantle, digestive gland and/or anus (depending on oyster size) were collected using a $4 \mathrm{~mm}$ diameter biopsy punch, placed in $360 \mathrm{ml}$ tissue lysis buffer, heated to $95^{\circ} \mathrm{C}$ for $10 \mathrm{~min}$, allowed to cool to $55^{\circ} \mathrm{C}$, and incubated at $55^{\circ} \mathrm{C}$ for 24 to $36 \mathrm{~h}$ after the addition of $40 \mathrm{ml}$ of $20 \mathrm{mg} \mathrm{ml}^{-1}$ Proteinase K. Two hun-

Table 1. Oligonucleotide primers used to amplify DNA in the multiplex PCR (MPCR)

\begin{tabular}{|c|c|c|c|c|c|}
\hline Species & $\begin{array}{l}\text { Forward } \\
\text { primer }\end{array}$ & $5^{\prime}$ to $3^{\prime}$ sequence & $\begin{array}{l}\text { Reverse } \\
\text { primer }\end{array}$ & $5^{\prime}$ to $3^{\prime}$ sequence & $\begin{array}{l}\text { Product } \\
\text { size (bp) }\end{array}$ \\
\hline Crassostrea virginica & H1fwd & GCTGGGAACTGTGGTGTTT & H1rev & GGCTGCCTTCACTTTCATT & 805 \\
\hline Haplosporidium nelsoni & $\operatorname{Msxf}^{\mathrm{a}}$ & TGGCATTAGGTTTCAGACCT & Msxr $^{a}$ & ATGTGTTGGTGACGCTAACC & 565 \\
\hline Perkinsus marinus & Dermo-fwd ${ }^{b}$ & CACTTGTATTGTGAAGCACCC & Dermo-rev ${ }^{\mathrm{c}}$ & GGTGACATCTCCAAATGACC & 305 \\
\hline Haplosporidium costale & sso \#2fwd ${ }^{\mathrm{d}}$ & CTGAGAAACGGCTACCACAT & sso \#2rev ${ }^{\mathrm{d}}$ & ACTTGGTGGTCGATAAGGCT & 149 \\
\hline
\end{tabular}


dred $\mathrm{ml}$ of lysed and homogenized sample was frozen at $-80^{\circ} \mathrm{C}$, and $200 \mathrm{ml}$ was further digested with $10 \mathrm{ml}$ of $100 \mathrm{mg} \mathrm{ml}^{-1}$ RNAse solution and loaded onto a silicagel membrane spin column for DNA extraction. Purified DNA was quantitated using a spectrophotometer and stored at $-80^{\circ} \mathrm{C}$

MPCRs were optimized consecutively in a GeneAmp PCR System 9600 thermal cycler following protocols outlined by Henegariu et al. (1997). Amplification reactions were carried out in $50 \mu \mathrm{l}$ volumes, each reaction mixture containing 450 to $550 \mathrm{ng}$ of purified DNA, $500 \mathrm{mM} \mathrm{KCl}, 100 \mathrm{mM}$ Tris- $\mathrm{HCl}\left(\mathrm{pH}\right.$ 8.3), $3 \mathrm{mM} \mathrm{MgCl}_{2}$, $200 \mathrm{mM}$ each dNTP, $1 \mathrm{U}$ of AmpliTaq Gold DNA polymerase, and 48,6, 12, and 18 pmol of each forward and reverse primer for Crassostrea virginica, Haplosporidium nelsoni, Perkinsus marinus, and $H$. costale, respectively. Reaction mixtures were heated to $94^{\circ} \mathrm{C}$ for $12 \mathrm{~min}$ and cycled 32 times at $94^{\circ} \mathrm{C}$ for $1 \mathrm{~min}, 62.5^{\circ} \mathrm{C}$ for $1 \mathrm{~min}$, and $72^{\circ} \mathrm{C}$ for $2 \mathrm{~min}$ for each cycle, with a final extension at $72^{\circ} \mathrm{C}$ for $7 \mathrm{~min}$. For each MPCR, a volume of $16 \mathrm{ml}$ was subjected to horizontal electrophoresis in $1.5 \%(\mathrm{w} / \mathrm{v})$ agarose gels. Amplification products for $C$. virginica, $H$. nelsoni, $P$. marinus, and $H$. costale were $805,565,305$, and 149 , respectively. Negative controls included a reaction mixture without template (i.e. reagent blank) and reaction mixtures with approximately $500 \mathrm{ng}$ of genomic DNA from either Salmo salar (Atlantic salmon) or Homarus americanus (American lobster) that underwent simultaneous extraction and purification with the oysters sampled in this study. Positive controls were mixtures of $1 \mathrm{ng}$ each of cloned SSU rDNA of $H$. nelsoni, $H$. costale, and 1 ng of cloned NTS DNA of $P$. marinus spiked into $500 \mathrm{ng}$ of genomic DNA from pathogen-free $C$. virginica. Preparation of cloned SSU rDNA of $H$. nelsoni and $H$. costale followed procedures described previously by Penna et al. (2001) based on original material kindly provided by Nancy Stokes (Virginia Institute of Marine Science, Gloucester Point, VA, USA). The intergenic NTS of $P$. marinus was amplified from genomic $P$. marinus DNA (ATCC strain LICT-1) using specific $P$. marinus primers described in this article, cloned into pGEM $\mathrm{T}$, and plasmid DNA was isolated using a Qiagen Plasmid Mini Kit.

In order to test the target specificity of primers in the context of the optimized MPCR, various artificial mixtures (6 combinations, $1 \mathrm{ng}$ parasite ${ }^{-1}$ ) of cloned DNA of Haplosporidium nelsoni, H. costale, and Perkinsus marinus were added to $500 \mathrm{ng}$ of genomic Crassostrea virginica DNA and were used as template for the MPCR. In addition, primer specificity was tested in MPCRs, using cloned SSU rDNA from $H$. louisiana and Urosporidium crescens, genomic DNA from Crassostrea gigas (Japanese oyster) and Mytilus galloprovincialis (Mediterranean mussel), and the freeliving and parasitic protozoa Paramoeba eilhardi and
Neoparamoeba pemaquidensis. MPCR products were cloned as previously described, and sequenced in an automated Applied Biosystems 377 DNA sequencer. Nucleotide sequences from 3 clones of each MPCR product were aligned using DNA analysis software and then compared to the NTS sequence of $P$. marinus (\#S78416) and the SSU rDNA sequences of $H$. nelsoni (\#U19538), H. costale (\#U20858), and LSU rDNA of $C$. virginica (\#AF137050).

Sensitivity of the MPCR was determined by spike/recovery. Serial 10 -fold dilutions of an initial mixture consisting of $1 \mu \mathrm{l}\left(100 \mathrm{ng} \mathrm{hl}^{-1}\right)$ each of cloned DNA of Haplosporidium nelsoni, H. costale, and Perkinsus marinus were spiked into a constant amount (500 ng) of genomic DNA of pathogen-free Crassostrea virginica, and used as templates for the MPCR.

Oysters (Crassostrea virginica) were collected from 18 sites at 12 locations along the Atlantic Coast and Gulf of Mexico of the United States between June 2000 and August 2001 (Fig. 1). Two of the sites, Oyster Bay, Long Island, New York, and Norwalk, Connecticut, were sampled year-round. The rest of the field stations were sampled once between June 6, 2000 and December 10,2000. In order to test and compare the results of this modified MPCR protocol to those of the RMFT assay and histopathological examination of tissue sections, individual oysters were subjected to all 3 diagnostic techniques to determine the presence of each

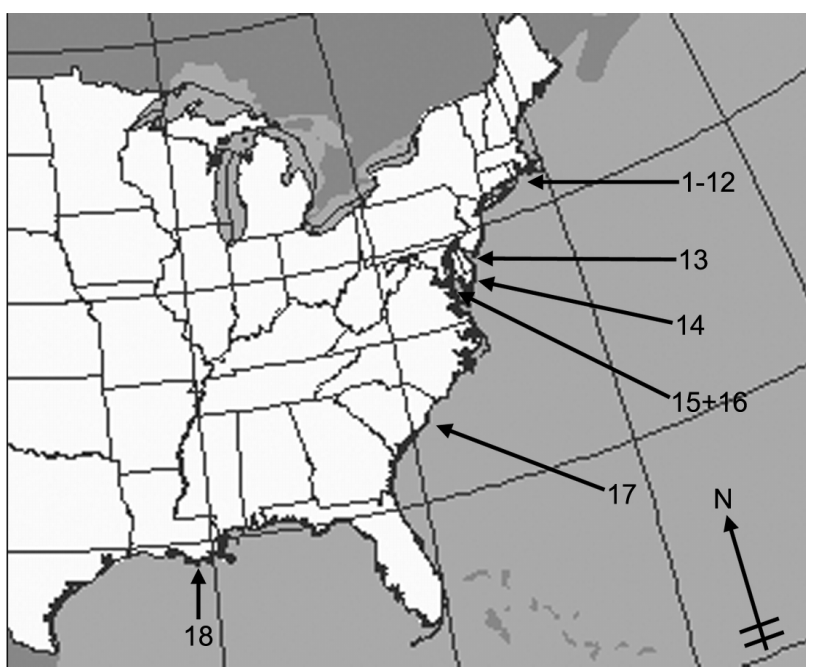

Fig. 1. Map of the East Coast of the United States indicating oyster collection sites. Site 1: Katama Bay, Martha's Vineyard, MA; Site 2: Barrington River, RI; Sites 3-6: Norwalk, CT; Site 7: Amagansett, Long Island, NY; Site 8: Mattituck Creek, Long Island, NY; Sites 9-12: Oyster Bay, Long Island, NY; Site 13: Port North, Delaware Bay, NJ; Site 14: Ocean City, Sinepuxent Bay, DE; Site 15: Lower Cedar Point, Potomac River, Chesapeake Bay, MD; Site 16: Cornfield Harbor, Potomac River, Chesapeake Bay, MD; Site 17: Clambank Creek North Inlet, SC; Site 18: Grand Isle, LA 
protozoan pathogen in each oyster. Upon receipt, oysters were examined grossly, measured and opened individually using aseptic technique. Tissues for the RMFT assay were sampled using a sterile $4 \mathrm{~mm}$ biopsy punch through the digestive gland and anus, and were cultured according to the methods of Ray (1966). Perkinsus marinus hypnospore counts were assigned a semi-quantitative estimate of infection based upon Mackin's scale (Mackin 1962). Tissues for DNA extraction and purification were sampled from the digestive gland, mantle and gill (approximately $25 \mathrm{mg}$ wet tissue) using a sterile $4 \mathrm{~mm}$ biopsy punch for each individual oyster. Oysters were then shucked and fixed in $10 \%$ neutral buffered formalin for $24 \mathrm{~h}$. Transverse sections through the visceral mass, mantle and gill were routinely processed for paraffin-embedding, sectioned at $4 \mathrm{~mm}$, stained with hematoxylin and eosin (H\&E), and examined by light microscopy.

Simultaneous amplification of the 4 target gene segments for Crassostrea virginica, Perkinsus marinus, Haplosporidium nelsoni, and Haplosporidium costale was achieved using PCR cycling parameters at a primer annealing temperature of $62.5^{\circ} \mathrm{C}$.

\section{RESULTS}

Primer specificity was tested in MPCR experiments using combinations of cloned DNA of Haplosporidium nelsoni, H. costale, and Perkinsus marinus added to genomic Crassostrea virginica DNA. There was no cross-reactivity between species (Fig. 2). In addition, when a single-species target DNA sequence was added to the MPCR reaction, DNA fragments of expected molecular weight resulted. When cloned SSU rDNA of $H$. nelsoni template alone was present in the MPCR mixture, an additional product of approximately $980 \mathrm{bp}$ was visualized above the targeted $565 \mathrm{bp}$ amplification product. However, in the optimized MPCR protocol containing the quality control target sequence of $C$. virginica and any other combination of target DNA templates, this higher molecular weight product of $H$. nelsoni was not detectable. Direct sequence analysis of cloned PCR amplification products revealed $100 \%$ homology to sequences obtained from GenBank.

PCR primers did not amplify the SSU rDNA from the related haplosporidians Haplosporidium louisiana or Urosporidium crescens or the free-living and parasitic protozoa Paramoeba eilhardi and Neoparamoeba pemaquidensis, which were chosen by virtue of their accessibility and prevalence in saltwater and freshwater culture conditions. The oyster primers did amplify a single, specific, 805 bp DNA fragment from both Crassostrea gigas and Mytilus galloprovincialis genomic DNA which was predictable based on the high degree of sequence homology that exists between the rRNA genes of C. virginica, C. gigas (GenBank \#AF137051), and M. edulis (GenBank \#AF339512). The fact that DNA of C. gigas and M. galloprovincialis is also amplifiable by this MPCR does not diminish the value of the $805 \mathrm{bp}$ product as a quality control target and may perhaps broaden the applicability of the MPCR to more host species.

After 1 round of MPCR amplification in spike/ recovery experiments, we were able to detect cloned DNA of Haplosporidium nelsoni, Perkinsus marinus, and $H$. costale in amounts of $100 \mathrm{fg}, 100 \mathrm{fg}$, and $10 \mathrm{pg}$, respectively (Fig. 3). Because $H$. nelsoni and $H$. costale have not been successfully cultured in vitro, and due to the fact that cloned DNA of $P$. marinus was used, we were not able to accurately estimate the limit of detection of the MPCR in terms of numbers of each parasite. However, MPCR was able to maintain similar levels of detection to that of single PCR amplifications for the detection of $H$. nelsoni (Stokes et al. 1995), P. marinus (Marsh et al. 1995, Robledo et al. 1998), and H. costale (Stokes \& Burreson 2001).

Comparative field trial results of PCR, RMFT and histological examination for diagnosis of the 3 pathogens are presented in Table 2. Each MPCR mixture contained a standardized 450 to $500 \mathrm{ng}$ of extracted DNA as template for the evaluation. The

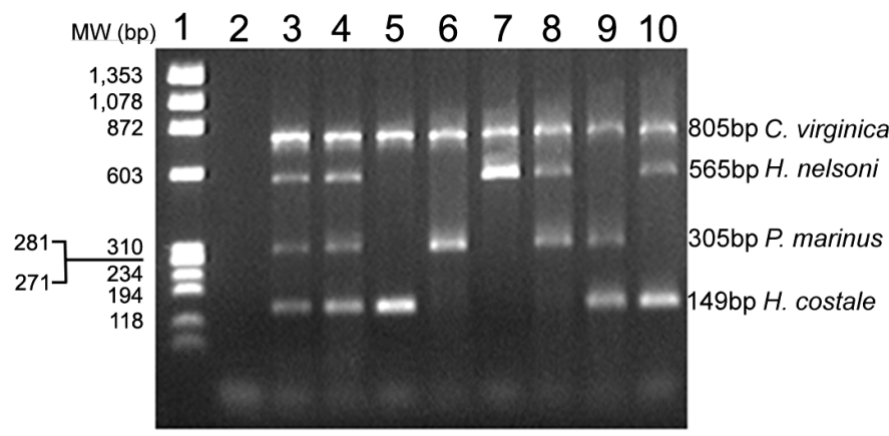

Fig. 2. Agarose gel electrophoresis of amplification products of the multiplex PCR (MPCR) demonstrating the specificity of the 4 sets of primers using various combinations of target cloned templates spiked into $500 \mathrm{ng}$ of genomic Crassostrea virginica DNA. Lane 1: Phi X 174/ Hae III double-stranded DNA ladder. Lane 2: reagent blank (no template). Lanes 3-10: MPCR using C. virginica, Haplosporidium nelsoni, $H$. costale, and Perkinsus marinus primer sets. Lanes 3 and 4: positive control (genomic $C$. virginica spiked with $1 \mathrm{ng}$ each of cloned $H$. nelsoni, $H$. costale, and P. marinus). Lane 5: genomic $C$. virginica and cloned $H$. costale. Lane 6: genomic $C$. virginica and cloned $P$. marinus. Lane 7 : genomic $C$. virginica and cloned $H$. nelsoni. Lane 8: genomic $C$. virginica with cloned $P$. marinus, and $H$. nelsoni. Lane 9: genomic $C$. virginica with cloned $P$. marinus, and $H$. costale. Lane 10: genomic $C$. virginica withcloned $H$. nelsoni, and $H$. costale. MW: molecular weight 


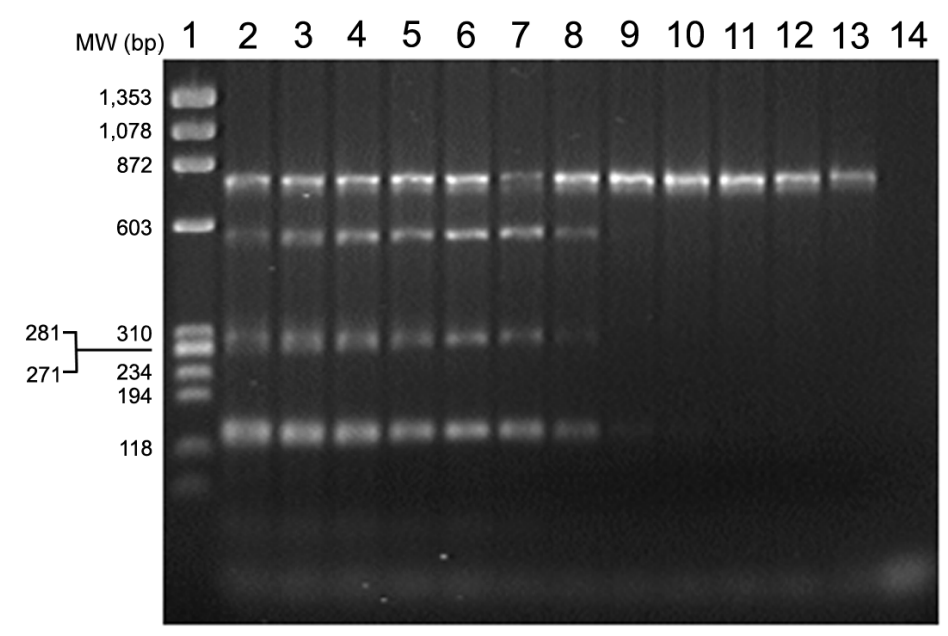

Fig. 3. Agarose gel electrophoresis of amplification products of the multiplex PCR (MPCR) demonstrating the sensitivity of the reaction. Lane 1: Phi X 174/Hae III double-stranded DNA ladder. Lanes 2-13: MPCR using 10-fold serial dilutions of an artificial mixture consisting of $1 \mathrm{ml}$ each of cloned NTS of Perkinsus marinus and cloned SSU rDNA of Haplosporidium nelsoni and $H$. costale spiked into $500 \mathrm{ng}$ of Crassostrea virginica genomic DNA. Lane 2: $100 \mathrm{ng}$. Lane 3: $10 \mathrm{ng}$. Lane 4: $1 \mathrm{ng}$. Lane 5: $100 \mathrm{pg}$. Lane 6: $10 \mathrm{pg}$. Lane 7: $1 \mathrm{pg}$. Lane 8: $100 \mathrm{fg}$. Lane 9: $10 \mathrm{fg}$. Lane 10: $1 \mathrm{fg}$. Lane 11: $0.1 \mathrm{fg}$. Lane 12: $0.01 \mathrm{fg}$. Lane 13: $0.001 \mathrm{fg}$. Lane 14: $500 \mathrm{ng}$ of Homarus americanus genomic DNA. MW: molecular wieght

Crassostrea virginica internal control was amplified in all 530/530 (100\%) sample reactions, and the MPCR was negative for each of the 3 pathogens in 188/530 (35\%) samples. Presence of the C. virginica amplifica-

Table 2. Comparative results of multiplex PCR (MPCR) assay, Ray/Mackin fluid thioglycollate (RMFT) assay and histological examination for the diagnosis of Perkinsus marinus, Haplosporidium nelsoni, and Haplosporidium costale $(\mathrm{n}=530)$. Results expressed as number positive

\begin{tabular}{|c|c|c|c|c|c|c|c|c|c|}
\hline \multirow{2}{*}{ Sampling site } & \multirow{2}{*}{$\begin{array}{l}\text { Sampling } \\
\text { date } \\
(\mathrm{m} / \mathrm{d} / \mathrm{yr})\end{array}$} & \multirow{2}{*}{$\begin{array}{l}\text { Sample } \\
\text { size } \\
\text { (n) }\end{array}$} & \multicolumn{3}{|c|}{ MPCR } & \multirow{2}{*}{ RMFT } & \multirow{2}{*}{\multicolumn{2}{|c|}{ 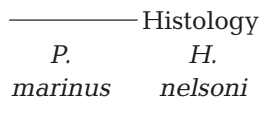 }} & \multirow[b]{2}{*}{$\begin{array}{c}H . \\
\text { costale }\end{array}$} \\
\hline & & & $\begin{array}{c}P . \\
\text { marinus }\end{array}$ & $\begin{array}{c}H . \\
\text { nelsoni }\end{array}$ & $\begin{array}{c}H . \\
\text { costale }\end{array}$ & & & & \\
\hline \multicolumn{10}{|l|}{ 1. Katama Bay, } \\
\hline Martha's Vineyard, MA & 09/22/00 & 30 & 0 & 0 & 0 & 0 & 0 & 0 & 0 \\
\hline 2. Barrington River, RI & $11 / 07 / 00$ & 30 & 25 & 6 & 1 & 26 & 27 & 1 & 1 \\
\hline 3. Norwalk, CT & $10 / 27 / 00$ & 30 & 12 & 6 & 0 & 18 & 6 & 2 & 2 \\
\hline 4. Norwalk, CT & 01/22/01 & 30 & 21 & 6 & 0 & 9 & 16 & 3 & 0 \\
\hline 5. Norwalk, CT & 04/26/01 & 30 & 23 & 11 & 0 & 4 & 9 & 0 & 0 \\
\hline 6. Norwalk, CT & 11/07/01 & 30 & 14 & 3 & 11 & 11 & 5 & 1 & 1 \\
\hline $\begin{array}{l}\text { 7. Amagansett, } \\
\text { Long Island, NY }\end{array}$ & 06/26/00 & 30 & 0 & 3 & 0 & 0 & 0 & 0 & 0 \\
\hline \multicolumn{10}{|l|}{ 8. Mattituck Creek, North } \\
\hline Fork, Long Island, NY & $09 / 27 / 00$ & 30 & 18 & 12 & 0 & 7 & 12 & 1 & 0 \\
\hline $\begin{array}{l}\text { 9. Oyster Bay, } \\
\text { Long Island, NY }\end{array}$ & $12 / 11 / 00$ & 30 & 0 & 8 & 0 & 3 & 0 & 1 & 0 \\
\hline $\begin{array}{l}\text { 10. Oyster Bay, } \\
\text { Long Island, NY }\end{array}$ & 03/16/01 & 30 & 3 & 9 & 0 & 0 & 3 & 2 & 0 \\
\hline \multicolumn{4}{|l|}{ 11. Oyster Bay, } & 11 & 0 & 3 & 0 & 6 & 0 \\
\hline $\begin{array}{l}\text { 12. Oyster Bay, } \\
\text { Long Island, NY }\end{array}$ & 08/15/01 & 20 & 1 & 10 & 0 & 1 & 2 & 5 & 0 \\
\hline \multicolumn{9}{|l|}{ 13. Portnorth, } & 0 \\
\hline $\begin{array}{l}\text { 14. Ocean City Inlet, } \\
\text { Sinepuxent Bay, DE }\end{array}$ & $11 / 16 / 00$ & 30 & 17 & 0 & 0 & 9 & 6 & 0 & 0 \\
\hline \multicolumn{9}{|l|}{$\begin{array}{l}\text { 15. Potomac River, left } \\
\text { channel Chesapeake }\end{array}$} & 0 \\
\hline $\begin{array}{l}\text { 16. Cornfield Harbor, } \\
\text { Potomac River, MD }\end{array}$ & \multicolumn{8}{|c|}{ 16. Cornfield Harbor, } & 0 \\
\hline \multicolumn{6}{|l|}{ 17. Clambank Creek, } & 22 & 11 & 1 & 0 \\
\hline \multirow[t]{3}{*}{ 18. Grand Isle, LA } & $11 / 29 / 00$ & 30 & 11 & 0 & 0 & 6 & 3 & 0 & 0 \\
\hline & Totals & 530 & 212 & 110 & 12 & 163 & 133 & 30 & 4 \\
\hline & revalence (\%) & & 40 & 21 & 2.3 & 31 & 25 & 6 & 0.8 \\
\hline
\end{tabular}


tion product in the absence of Haplosporidium nelsoni, H. costale, and Perkinsus marinus MPCR products illustrates that template DNA preparations were of sufficient quality to have been amplified, and that reactions were executed properly, but that the target DNA was absent, thereby validating DNA extraction quality, PCR conditions, and interpretation of these results as negative for the presence of protozoan pathogens.

\section{DISCUSSION}

The results of 530 oysters tested in this study indicate that MPCR diagnosis of Haplosporidium nelsoni, $H$. costale, and Perkinsus marinus is a reliable alternative diagnostic test to histopathological examination and the RMFT assay. The main advantage of the MPCR is its simultaneous, rapid detection of 3 pathogens, along with an internal DNA quality control standard, using a single test. DNA quality control testing could have been accommodated by a separate $\mathrm{PCR}_{\text {; however, }}$ inclusion of a host genetic target into a single MPCR reduced PCR set-up and run times, as well as reagent consumption, in a large-scale application such as ours. In this study, total time from receiving oysters to detection of amplified DNA by agarose gel electrophoresis was 36 to $48 \mathrm{~h}$. Traditional pathogen diagnosis by RMFT assay or histopathological examination ranged from 5 to $7 \mathrm{~d}$. $H$. nelsoni, $H$. costale, and P. marinus were detected by all 3 diagnostic techniques, but the MPCR detected a greater prevalence of infection by each parasite, regardless of mixed infections and infection density, when compared to other traditional tests. For the detection of $H$. nelsoni and $H$. costale, the specificity of the primers alleviates the problems associated with histomorphological differentiation of plasmodia in the absence of species-defining spores.

Our results indicate that the MPCR is able to detect oysters infected with Perkinsus marinus and Haplosporidium nelsoni throughout the respective geographic range of each parasite. The absence and low prevalence of $H$. costale from endemic and historically non-endemic regions prevented us from properly assessing the MPCR's ability to detect $H$. costaleinfected oysters. Greater numbers of sampling sites from endemic coastal regions Virginia, Maryland, Delaware, and New Jersey are required to adequately compare these 2 diagnostic techniques. However, as with any diagnostic test which does not utilize the entire host organism for the detection of infectious agents, low infection densities, localized infections, and tissue-sampling techniques may account for false negative interpretation of results (Stokes et al. 1995). In addition, the 11 of $12(2 \%) H$. costale infections detected by MPCR at Site 6 (Norwalk, CT, November 7 , 2001) may have resulted from laboratory error, which would enhance detection results. However, attempts to prevent laboratory contamination included use of an aseptic technique to obtain tissue samples and PCR extraction and amplification of negative controls. Moreover, a second round of DNA extraction, purification and amplification (including extraction controls) was carried out on $-80^{\circ} \mathrm{C}$ stored samples to verify our results. Similarly, small numbers of histological or RMFT-positive/MPCR-negative samples were identified from the 530 oysters sampled. Some discrepancies between RMFT and MPCR results are likely due to the lack of specificity of the RMFT assay, which can yield false positive results because of its inability to discriminate between Perkinsus spp. (Robledo et al. 1998) or the presence of Perkinsus spp. other than $P$. marinus (Kotob 1999, McLaughlin et al. 2000, Coss et at. 2001). All oysters positive for RMFT and negative for MPCR were light infections (0.5) as determined by the Mackin scale of Perkinsus infection (Mackin 1962).

The wide range of geographical and environmental field-collected samples to which this MPCR was applied demonstrates its utility for Perkinsus marinus and Haplosporidium nelsoni in broad-range, largescale surveillance programs where rapid and accurate detection of these protozoan parasites may be necessary. The usefulness of this modified MPCR will need to be explored in future applications related to oyster health and disease management, e.g. screening oysters prior to importation or transplantation, seed certification, identifying point sources of infection, and maybe elucidating unidentified life cycle stages in alternative hosts.

Acknowledgements. Financial support was provided by the Northern Regional Aquaculture Center (\#556505).

\section{LITERATURE CITED}

Andrews JD, Castagna M (1978) Epizootiology of Minchinia costalis in susceptible oysters in seaside bays of Virginia's eastern shore, 1956-1976. J Invertebr Pathol 32:124-138

Andrews JD, Hewatt WG (1957) Oyster mortality studies in Virginia. II. The fungus disease caused by Dermocystidium marina in oysters in Chesapeake Bay. Ecol Monogr 27:1-26

Barber BJ, Langan R, Howell TL (1997) Haplosporidium nelsoni (MSX) epizootic in the Piscataqua River Estuary (Maine/New Hampshire, USA). J Parasitol 83:148-150

Brightwell G, Pearce M, Leslie D (1998) Development of internal controls for PCR detection of Bacillus anthracis. Mol Cell Probes 12:367-377

Bushek D, Ford SE, Allen SK (1994) Evaluation of methods using Ray's fluid thiglycollate medium for diagnosis of Perkinsus marinus infection in the eastern oyster, Crassostrea virginica. Annu Rev Fish Dis 4:201-217

Coss CA, Robledo JA, Ruiz GM, Vasta GR (2001) Description 
of Perkinsus andrewsi n. sp. isolated from Baltic clam (Macoma balthica) by characterization of the ribosomal RNA locus, and development of a species-specific PCRbased diagnostic assay. J Eukaryot Microbiol 48(1):52-61

Haskin HH, Stauber LA, Mackin JA (1966) Minchinia nelsoni n. sp. (Haplosporidia, Haplosporidiidae): causative agent of the Delaware Bay oyster epizootic. Science 153:1414-1416

Henegariu O, Heerema NA, Dloughy SR, Vance GH, Vogt PH (1997) Multiplex PCR: critical parameters and step-bystep protocol. Biotechniques 23:504-511

Kleinschuster S, Parent J (1995) Sub-clinical infection of oysters (Crassostrea virginica) (Gmelin 1791) from Maine by species of the genus Perkinsus (Apicomplexa). J Shellfish Res 14:489-491

Ko YT, Ford SE, Fong D (1995) Characterization of the small subunit ribosomal RNA gene of the oyster parasite Haplosporidium costale. Mol Mar Biol Biotech 4:236-240

Kotob SI, McLaughlin SM, Van Berkum P, Faisal M (1999) Discrimination between 2 Perkinsus spp. isolated from the softshell clam, Mya arenaria, by sequence analysis of 2 internal transcribed spacer regions and the $5.8 \mathrm{~S}$ ribosomal RNA gene. Parasitology 119:363-8

Mackin JG (1962) Oyster diseases caused by Dermocystidium marinum and other microorganisms in Louisiana. Publ Inst Mar Sci Univ Tex 7:132-229

Mackin JG, Owen HM, Collier A (1950) Preliminary note on the occurrence of a new protozoan parasite, Dermocystidium marinum n. sp., in Crassostrea virginica (Gmelin). Science 111:328-329

Marsh AG, Gauthier JD, Vasta GR (1995) A semiquantitative PCR assay for assessing Perkinsus marinus infections in the eastern oyster, Crassostrea virginica. J Parasitol 81: $577-583$

McLaughlin SM, Tall BD, Shaheen A, Elsayed EE, Faisal M (2000) Zoosporulation of a new Perkinsus species isolated from the gills of the softshell clam Mya arenaria. Parasite $20007: 115-22$

Penna S, Khan, MI, French RA (2001) Development of a mul-

Editorial responsibility: Carey Cunningham,

Aberdeen, UK tiplex PCR for the detection of Haplosporidium nelsoni Haplosporidium costale and Perkinsus marinus in the eastern oyster (Crassostrea virginica, Gmelin 1791). Mol Cell Probes 15:385-390

Ray SM (1952) A culture technique for the diagnosis of infection with Dermocystidium marinum Mackin, Owen and Collier in oysters. Science 116:360-361

Ray SM (1966) A review on the culture method for detecting Dermocystidium marinum, with suggested modification and precautions. Proc Natl Shellfish Assoc 54:55-69

Robledo JA, Gauthier JD, Coss CA, Wright AC, Vasta GR (1998) Species-specificity and sensitivity of a PCR-based assay for Perkinsus marinus in the eastern oyster, Crassostrea virginica: a comparison with the fluid thioglycollate assay. J Parasitol 84:1237-1244

Robledo JA, Coss CA, Vasta GR (2000) Characterization of the ribosomal RNA locus of Perkinsus atlanticus and development of a polymerase chain reaction-based diagnostic assay. J Parasitol 86:972-978

Sachadyn P, Kur J (1998) The construction and use of a PCR internal control. Mol Cell Probes 12:259-262

Stokes NA, Burreson EM (1995) A sensitive and specific DNA probe for the oyster pathogen Haplosporidium nelsoni. J Eukaryot Microbiol 42:350-357

Stokes NA, Burreson EM (2001) Differential diagnosis of mixed Haplosporidium costale and Haplosporidium nelsoni infections in the eastern oyster Crassostrea virginica, using DNA probes. J Shellfish Res 20:207-213

Stokes NA, Siddall ME, Burreson EM (1995) Detection of Haplosporidium nelsoni (Haplosporidia: Haplosporidiidae) in oysters by PCR amplification. Dis Aquat Org 23: $145-152$

Sunila I, Karolus J, Volk J (1999) A new epizootic of Haplosporidia (MSX), a haplosporidian oyster parasite, in Long Island Sound. J Shellfish Res 18:169-174

Wood JL, Andrews JD (1962) Haplosporidium costale (sporozoa) associated with a disease of Virginia oysters. Science 136:710-711

Submitted: February 11, 2002; Accepted: June 5, 2003 Proofs received from author(s): March 5, 2004 